\title{
Thoracic aortic aneurysms after blunt trauma
}

\author{
Künt travmalardan sonra oluşan torasik aort anevrizmaları
}

\author{
İrfan TAŞOĞLU, Doğan Emre SERT, Gökhan LAFÇI, Bahadır GENÇ, \\ Kemal KAVASOĞLU, Ahmet Tulga ULUS, Mustafa PAÇ
}

\section{BACKGROUND}

Aortic injury after blunt trauma that is missed during the first admission will soon be seen as a chronic aneurysm. The objective of this study is to show the importance of the diagnosis and appropriate treatment of these aneurysms.

\section{METHODS}

Between 2009 and 2012, 8 patients (mean age, 50 \pm 31 years) diagnosed with chronic traumatic aortic aneurysm were treated with either thoracic endovascular aortic repair (TEVAR) or conventional surgery 20 years on average after the trauma.

\section{RESULTS}

Treatments included TEVAR in four patients, conventional surgery in two patients, and hybrid intervention in one patient. One patient died postoperatively. One patient had an endoleak requiring a repeat TEVAR, which was successful. Brachial embolectomy was performed after placing the endovascular stent. No paraplegia or lower extremity ischemia was seen. One patient died preoperatively due to rupture of the aneurysm.

\section{CONCLUSION}

Chronic traumatic aortic aneurysms may cause general symptoms years after a blunt trauma. Aortic injury must always be considered in the assessment and follow-up of trauma patients.

Key Words: Blunt; chronic aortic aneurysms; TEVAR; trauma.

\section{$\boldsymbol{A M A C}$}

Künt travmalardan sonra oluşan aort hasarı erken dönemde tanı almayıp yıllar içinde yaşamı tehlikeye atan kronik anevrizmalar şeklinde görülebilir. Bu çalışmanın amacı, bu anevrizmaların tanı ve uygun tedavisinin önemini göstermektir.

\section{GEREÇ VE YÖNTEM}

2009-2012 arasında kronik travmatik aort anevrizması tanısı alan sekiz hasta (ortalama $50 \pm 31$ yaş), travmadan ortalama 20 yıl sonra torasik endovasküler aort tamiri (TEVAR) ya da açık cerrahi ile tedavi edildi.

\section{BULGULAR}

Sekiz hastanın dört tanesi TEVAR, iki tanesi açık cerrahi, bir tanesi ise hibrid girişimle tedavi edildi. Bir hasta ameliyat sonrası dönemde hayatını kaybederken, bir tanesine tip 1 endoleak nedeniyle tekrar başarılı TEVAR işlemi uygulandı; bir hastaya ise endovasküler greft sonrası tespit edilen brakiyal emboli nedeniyle embolektomi yapıldı. Parapleji, alt ekstremite iskemisi ve başka bir komplikasyon görüldi. Bir hasta ameliyat öncesi dönemde anevrizma rüptürüne bağlı olarak hayatını kaybetti.

\section{SONUÇ}

Künt travmalara bağlı aort anevrizmaları, travmadan yıllar sonra genel olarak görülen semptomlara yol açabilir. Travma hastasının izlem ve takibinde aortik anevrizma mutlaka akılda tutulmalıdır.

Anahtar Sözcükler: Künt; kronik aortik anevrizma; TEVAR; travma.
Blunt non-penetrating aortic injuries are very mortal lesions, with a high mortality rate, with $80-90 \%$ dying in the first hour after the accident, and these injuries have been implicated as the second most common cause of death in the trauma patient. ${ }^{[1,2]}$ In approximately $2 \%$ of these patients, though the injury is missed during the first admission, patients live long enough to develop a chronic aortic aneurysm, which signifies rupture. ${ }^{[3]}$ Ankara. 
These patients can present with general symptoms like cough, hoarseness and pain in the epigastrium or back years after the accident. The most common symptom was hoarseness in our patients.

The objective of this study was to emphasize the importance of early imaging in trauma patients and to keep aortic blunt injury in mind when obtaining a medical history of the patient with such symptoms.

\section{MATERIALS AND METHODS}

From August 2009 to April 2012, we selected eight patients with a history of blunt trauma - 7 males and 1 female - from 128 descending aortic aneurysm patients admitted to and treated in our department (Table 1). The study population's mean age was $50 \pm 31$ years (median, 54 years; range, 30-61). All patients had a history of blunt trauma. Five $(62.5 \%)$ of them had a previous motor vehicle accident, $2(25 \%)$ had an accidental fall and $1(12.5 \%)$ was exposed to a long vehicle sudden tire blowout. Demographic characteristics, operation data, postoperative course, and intensive care unit and ward complications were collected from hospital medical records. In all the cases, thoracoabdominal computed tomography angiography (CTA) with an interval slice of 1 millimeter was performed to evaluate the entire aorta and possible accompanying injuries of the other organ systems. Three-dimensional (3D) reconstruction of the images was performed. A cardiovascular interventional team involving cardiothoracic surgeons and interventional radiologists then discussed and decided on the procedure. After discharge, patients were called in for follow-up at the first week, first month and sixth month.

\section{RESULTS}

Patients' ages ranged from 30 to 61 years, and the median age was 54 . The interval between the time of injury and surgical intervention ( 8 patients) ranged from 18 days to 44 years (mean, 20 years). Types of aortic lesions were descending thoracic aortic aneurysm in 7 patients and combined arch and descending aortic aneurysm in 1 patient. Six patients $(75 \%)$ had a saccular type and two (25\%) had fusiform aneurysms. We presumed the etiology of the aneurysms as trauma for the following reasons: The patients were not elderly and had no systemic inflammatory disease, and their physical examination criteria were not concordant with Marfan syndrome. Furthermore, they had no hypertension, no documented atherosclerotic vascular disease, no documented prior chronic infectious state (syphilis, brucella), and no family history of aneurysms, and lab values of infectious markers were normal. All had a serious trauma history. Hoarseness was the most common symptom. None of them was in critical condition. According to the medical records, none of them, at first admission after trauma, was assessed with thoracic CT, and thus were not diagnosed.

Four patients underwent thoracic endovascular aortic repair (TEVAR), two patients underwent a conventional surgical operation in which a Dacron graft interposition was performed, and one patient, who had arch and descending aortic aneurysm, underwent a hybrid intervention. Cardiopulmonary bypass (CPB) was administered via brachial artery cannulation. Branches of the arcus aorta were anastomosed to the

Table 1. Clinical features of the patients with thoracic aortic aneurysms

\begin{tabular}{|c|c|c|c|c|c|c|c|c|c|}
\hline Patient & $\begin{array}{c}\text { Age } \\
\text { (years) }\end{array}$ & Gender & Interval & $\begin{array}{l}\text { Clinical } \\
\text { symptom }\end{array}$ & $\begin{array}{c}\text { Type of } \\
\text { aneurysm }\end{array}$ & $\begin{array}{c}\text { Aneurysm } \\
\text { Diameter }(\mathrm{mm})\end{array}$ & Etiology & Operation & Complication \\
\hline 1 & 54 & Male & $30 \mathrm{yrs}$ & Hoarse voice & Saccular & $21 \times 18$ & Downfall & TEVAR & $\begin{array}{c}\text { Type } 1 \\
\text { endoleak }\end{array}$ \\
\hline 2 & 30 & Female & $11 \mathrm{yrs}$ & Back pain & Saccular & $33 \times 44$ & $\begin{array}{l}\text { Motor vehicle } \\
\text { accident }\end{array}$ & $\begin{array}{l}\text { Left thoracotomy, } \\
\text { greft interposition }\end{array}$ & None \\
\hline 3 & 61 & Male & $9 \mathrm{yrs}$ & Hoarse voice & Saccular & $45 \times 21$ & $\begin{array}{l}\text { Motor vehicle } \\
\text { accident }\end{array}$ & TEVAR & None \\
\hline 4 & 52 & Male & 44 yrs & Epigastric pain & Fusiform & 90 & $\begin{array}{l}\text { Motor Vehicle } \\
\text { accident }\end{array}$ & TEVAR & None \\
\hline 5 & 56 & Male & $39 \mathrm{yrs}$ & Hoarse voice & Fusiform & 70 & $\begin{array}{l}\text { Motor Vehicle } \\
\text { accident }\end{array}$ & Hybrid & Exitus \\
\hline 6 & 41 & Male & $6 \mathrm{yrs}$ & Hoarse voice & Saccular & $50 \times 36$ & Tyre burst & TEVAR & $\begin{array}{l}\text { Brachial } \\
\text { embolus }\end{array}$ \\
\hline 7 & 58 & Male & $3 \mathrm{yrs}$ & Back pain & Saccular & $41 \times 24$ & Downfall & $\begin{array}{l}\text { Thoracotomy, } \\
\text { graft interposition }\end{array}$ & None \\
\hline 8 & 54 & Male & 18 days & $\begin{array}{c}\text { Hoarseness } \\
\text { and dysphagia }\end{array}$ & Saccular & 75 & $\begin{array}{l}\text { Motor vehicle } \\
\text { accident }\end{array}$ & $\begin{array}{c}\text { Died } \\
\text { preoperatively }\end{array}$ & Exitus \\
\hline
\end{tabular}

Interval: Time between injury and treatment. 

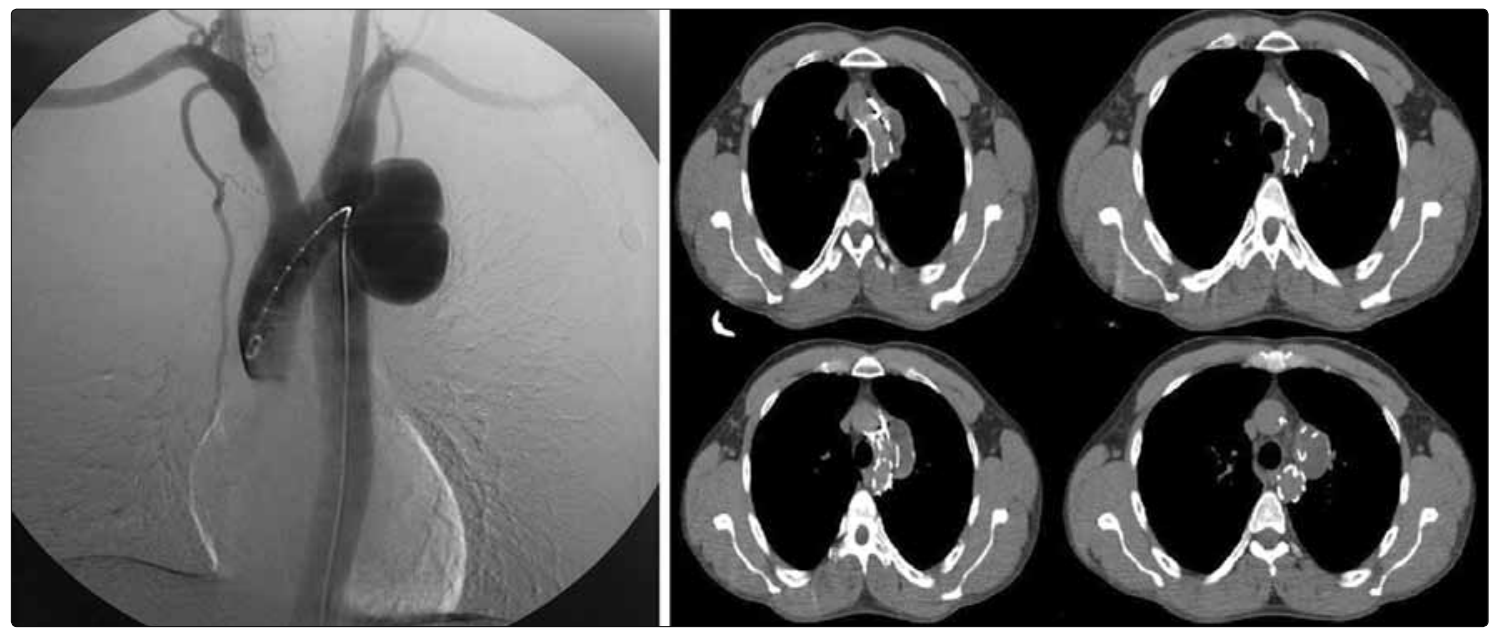

Fig. 1. Preoperative digital subtraction angiography (DSA) and postoperative CTA of Patient 6 after successful TEVAR.

Dacron graft, which was placed in the ascending aorta. Afterwards, the endovascular stent graft was placed in the proximal part of the arcus and descending aorta. No complications were seen. He was transferred to the ward on the first postoperative day. One patient was lost on the postoperative fifth day due to sudden death.

We covered the subclavian artery in two patients. During and after the procedure, follow-up was made with routine physical examination and Doppler ultrasonography (USG). We do not surgically intervene unless there are ischemic signs. These patients had no ischemic sign or loss of motor function at discharge or during the follow-up. One (Patient 6) had a left upper extremity ischemia due to an embolus after placing the endovascular stent. Embolectomy was performed and monophasic flow was administered.

Patient 1 had an endoleak at the first month followup, and TEVAR was repeated successfully. No paraplegia was seen. Femoral arteries were repaired with
Prolene sutures in TEVAR patients after the procedure and no ischemia was seen. Six patients were discharged from the hospital. Patient 6 had monophasic left upper extremity blood flow, documented with Doppler USG. Six other patients had no ischemic signs. Patient 8 had a history of a motor vehicle accident, 18 days before admission. He was diagnosed with saccular descending aortic aneurysm and urgent TEVAR was planned. However, he suffered sudden cardiac arrest and was immediately transferred to the operating theater. Left thoracotomy was performed and rupture of the aneurysm was documented. Despite all attempts, he could not be saved.

Routine follow-up at the sixth month with CTA did not reveal any endoleaks. Aneurysmatic sacs were thrombosed. We did not observe aortic diameter increase in any of the patients. No ischemia was seen in the upper and lower extremities. Patients' symptoms disappeared 15 days after the intervention on average.
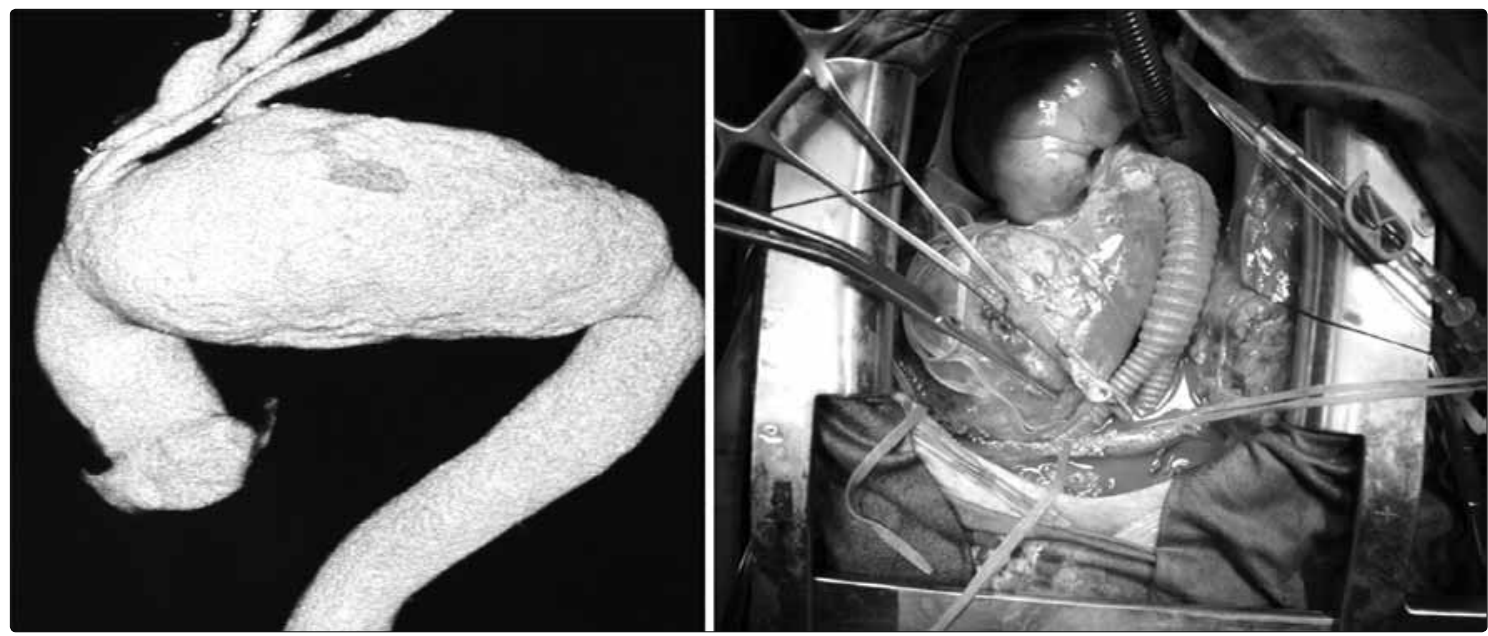

Fig. 2. Preoperative and intraoperative images of Patient 5. After surgical rebranching, endovascular stent graft was placed into the arcus and descending aorta. 


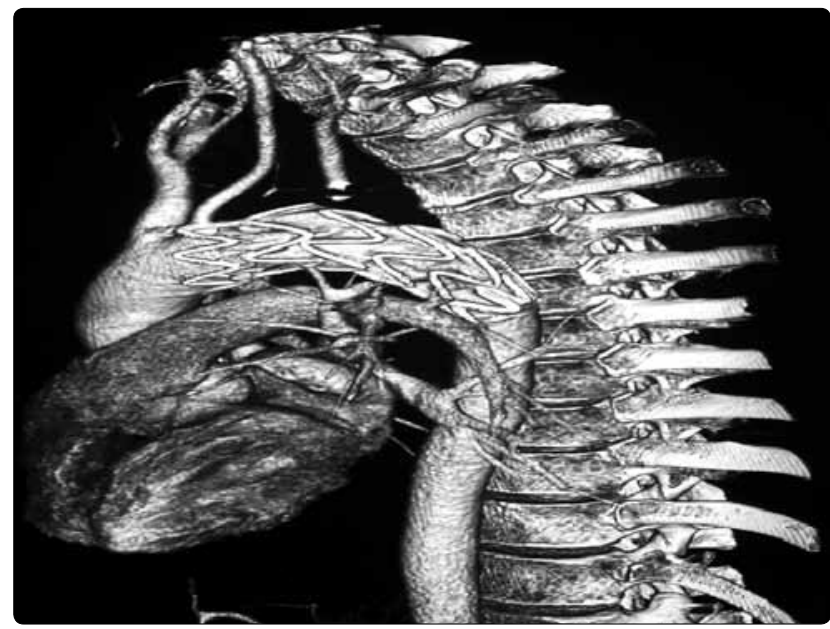

Fig. 3. CTA image at the 6th month follow-up of Patient 4.

\section{DISCUSSION}

Traumatic thoracic aortic injuries are uncommonbut highly lethal-injuries. Regardless of whether the injury is caused by blunt or penetrating trauma, the majority of the patients die immediately. Without appropriate treatment, up to $50 \%$ of the initial survivors will die within the first 72 hours. ${ }^{[1,4]}$ In $1-2 \%$ of patients with traumatic aortic injury, the problem is not identified initially and they survive long enough to develop a chronic traumatic false aneurysm. ${ }^{[3,4]}$ In 275 cases of traumatic aortic rupture reported by Parmley and colleagues, ${ }^{[4]} 239$ (88\%) died during the first hour, 28 $(10 \%)$ within two weeks, and others after 22,50 , and 76 days. Only five patients (2\%) survived long enough to develop a chronic traumatic aneurysm.

Traumatic thoracic aortic injuries are usually located distal to the left subclavian artery. ${ }^{[5]}$ Intercostal arteries, pleura and the ligamentum arteriosum fix the descending aorta more rigidly than the aortic arch and the heart during its course through the vertebral sulcus. During a horizontal deceleration trauma, the descending and other parts of the aorta move at different speeds. As a result, the isthmic part of the aorta is under maximum stress, and thus may yield total or partial rupture of the vessel. Direct loading of the pressurized descending thoracic aorta causes isthmus injury secondary to aortic wall strain. Deep medial lesions are common and could propagate soon after injury to form pseudoaneurysms. ${ }^{[6]}$ Among the patients presented to our clinic, all but one had aneurysms distal to the subclavian artery (87.5\%) and $75 \%$ were saccular. The interval between the trauma and diagnosis used in the literature to differentiate acute and chronic traumatic aortic injuries is not clear, varying between 36 hours and 3 months. ${ }^{[7,8]}$ The interval between the trauma and diagnosis of a pseudoaneurysm may change. In a group of 10 patients operated for traumatic thoracic aortic aneurysms, Buket et al. ${ }^{[9]}$ reported this period to

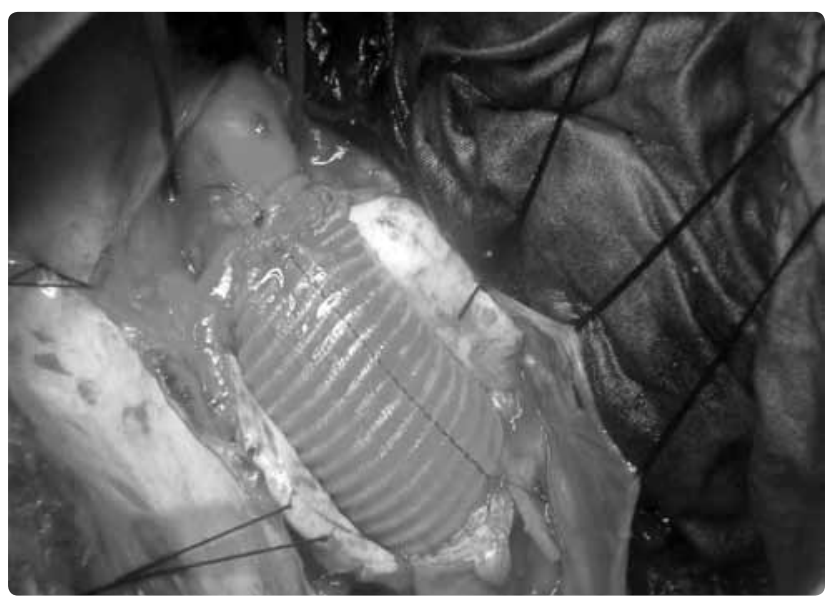

Fig. 4. Patient 2 after interpositioning of the Dacron graft to the descending aorta via left thoracotomy.

be between 1 day and 10 years. In our study, the most common symptom was hoarseness, and the mean interval between the injury and symptom was 19 years (range, 18 days- 44 years).

In a literature review by Bennett and Cherry, ${ }^{[10]} 104$ chronic traumatic aortic aneurysms were identified; $50 \%$ of patients eventually developed symptoms, and $21 \%$ manifested radiological evidence of expansion. Moreover, late rupture occurred in nine patients. In a similar study, Finkelmeier et al. ${ }^{[3]}$ analyzed all the reported cases of chronic traumatic aneurysms between 1950 and 1980. Among 413 patients, 60 were followed without surgical intervention. The survival rates at 5 and 10 years in the unoperated patients were $70 \%$ and $65 \%$, respectively. Of these, $20(33 \%)$ died of aortic rupture or complications related to the chronic traumatic aneurysm.

TEVAR is a less invasive procedure than conventional surgery. Irace and colleagues ${ }^{[2]}$ reported a series of 16 patients with chronic aortic aneurysm who underwent endovascular treatment. One mortality was reported due to disseminated intravascular coagulation. They observed one type 1 endoleak. Demers and colleagues ${ }^{[1]}$ lost one patient in a series of 15 patients with chronic aortic aneurysms treated with stent-grafts.

Caronno and colleagues ${ }^{[1]}$ reported a series of 11 patients with intentional coverage of the left subclavian artery during stent-grafting of the thoracic aorta. They reported no related complications. In a series of 58 patients, Schoder et al. ${ }^{[12]}$ overstented the left subclavian artery during TEVAR, and complete occlusion was seen in eight and partial occlusion in 24 patients. On the other hand, Caffarelli et al. ${ }^{[13]}$ studied 53 patients who were identified as having blunt aortic injury. Of the 53 patients, 29 underwent planned, nonoperative management, and of these, in-hospital survival was $93 \%$, with no aortic deaths in the remaining patients. 
In our study, we used isolated TEVAR in five of our eight patients. One patient underwent a hybrid procedure. In the TEVAR group, we reported one brachial embolectomy, and one type 1 endoleak, requiring repeat TEVAR. Patients undergoing conventional surgery had no problems during the follow-ups. Patient 8 was diagnosed 18 days after a vehicle accident but died preoperatively due to the rupture of the aneurysm. He could have been saved if diagnosed at the first admission to the trauma center, which shows the importance of early diagnosis in these patients.

The limitations of our study are the small number of the patients, and the fact that, since patients that are subject of injury very rarely present to our department, we cannot give the percentage of aortic injury after trauma. Thirdly, none of our patients was assessed with CTA at the first admission after trauma, so we do not have any idea about the onset or course of the developing aneurysm.

In conclusion, chronic traumatic aneurysms have different anatomic characteristics than degenerative aneurysms; they are typically localized, calcified saccular lesions located just distal to the left subclavian artery.

Thoracic aortic aneurysms can be seen after blunt trauma. One to two percent of these patients, who injury is missed at the first admission, develop chronic false aneurysms. ${ }^{[3,4]}$ These patients present with unspecific symptoms like cough, hoarseness, and epigastric and back pain months or even years after the accident. We emphasize herein the importance of proper imaging, follow-up and diagnosis of aortic injury after blunt trauma, which can be managed successfully when diagnosed early. Especially in the late follow-up of these patients, the development of complications due to aneurysms after blunt aortic trauma should be considered.

Conflict-of-interest issues regarding the authorship or article: None declared.

\section{REFERENCES}

1. Demers P, Miller C, Scott Mitchell R, Kee ST, Lynn Cha- gonjian RN, Dake MD. Chronic traumatic aneurysms of the descending thoracic aorta: mid-term results of endovascular repair using first and second-generation stent-grafts. Eur J Cardiothorac Surg 2004;25:394-400.

2. Irace L, Laurito A, Venosi S, Irace FG, Malay A, Gossetti $\mathrm{B}$, et al. Mid- and long-term results of endovascular treatment in thoracic aorta blunt trauma. ScientificWorldJournal 2012;2012:396873.

3. Finkelmeier BA, Mentzer RM Jr, Kaiser DL, Tegtmeyer CJ, Nolan SP. Chronic traumatic thoracic aneurysm. Influence of operative treatment on natural history: an analysis of reported cases, 1950-1980. J Thorac Cardiovasc Surg 1982;84:25766.

4. Parmley LF, Mattingly TW, Manion WC, Jahnke EJ Jr. Nonpenetrating traumatic injury of the aorta. Circulation 1958;17:1086-101.

5. Yilmaz O, Arbatli H, Sirin G, Arpaz M, Yagan NE, Numan F, et al. Endovascular treatment of traumatic thoracic aortic aneurysms: report of five cases and review of the literature. Ulus Travma Acil Cerrahi Derg 2010;16:575-8.

6. Schmoker JD, Lee CH, Taylor RG, Chung A, Trombley L, Hardin N, et al. A novel model of blunt thoracic aortic injury: a mechanism confirmed? J Trauma 2008;64:923-31.

7. Kato N, Dake MD, Miller DC, Semba CP, Mitchell RS, Razavi MK, et al. Traumatic thoracic aortic aneurysm: treatment with endovascular stent-grafts. Radiology 1997;205:657-62.

8. Rousseau H, Soula P, Perreault P, Bui B, Janne d'Othée B, Massabuau $P$, et al. Delayed treatment of traumatic rupture of the thoracic aorta with endoluminal covered stent. Circulation 1999;99:498-504.

9. Buket S, Yağdı T, Çıkrıkçıŏlu M. Aortanın travmatik lezyonları. İçinde: Buket S, Yağdı T, editör. Aort cerrahisi. İstanbul: Yüce Reklam Yayım Dağıtım A.Ş.; 2003. s. 40537.

10. Bennett DE, Cherry JK. The natural history of traumatic aneurysms of the aorta. Surgery 1967;61:516-23.

11. Caronno R, Piffaretti G, Tozzi M, Lomazzi C, Rivolta N, Castelli P. Intentional coverage of the left subclavian artery during endovascular stent graft repair for thoracic aortic disease. Surg Endosc 2006;20:915-8.

12. Schoder M, Grabenwöger M, Hölzenbein T, Cejna M, Ehrlich MP, Rand T, et al. Endovascular repair of the thoracic aorta necessitating anchoring of the stent graft across the arch vessels. J Thorac Cardiovasc Surg 2006;131:380-7.

13. Caffarelli AD, Mallidi HR, Maggio PM, Spain DA, Miller DC, Mitchell RS. Early outcomes of deliberate nonoperative management for blunt thoracic aortic injury in trauma. J Thorac Cardiovasc Surg 2010;140:598-605. 